\title{
Kariyer Yelkenlisi Modeline Dayalı Grupla Müdahale Programı*
}

\section{Group Intervention Program Based on Career Sailing Model}

\author{
Betül Gökçen Doğan Laçin, ${ }^{\text {a,** }}$ Binnur Yeşilyaprak ${ }^{\mathrm{b}}$ \\ a Arş. Gör., Ankara Üniversitesi, Eğitim Bilimleri Fakültesi, Rehberlik ve Psikolojik Danışmanlık Bölümü, 06590, Ankara/Türkiye. \\ ORCID: 0000-0001-7697-3341
}

${ }^{\text {b }}$ Prof. Dr., Ankara Üniversitesi, Eğitim Bilimleri Fakültesi, Eğitimde Psikolojik Hizmetler Bölümü, 06590, Ankara/Türkiye. ORCID: 0000-0002-8949-6801

\section{MAKALE BILGİSİ}

\section{Makale Geçmişi:}

Başvuru tarihi: 22 Ekim 2017

Düzeltme tarihi: 17 Şubat 2018

Kabul tarihi: 01 Mart 2018

\section{Anahtar Kelimeler:}

Grupla Psikolojik Danışma

Kariyer Danışmanlığı

Kariyer Yelkenlisi Modeli

\section{ARTICLE INFO}

Article history:

Received 22 October 2017

Received in revised form 17 February 2018

Accepted 01 March 2018

\section{Keywords:}

Group Counseling

Career Sailing Model

Career Counseling

\section{ÖZ}

$\mathrm{Bu}$ çalışmada kariyer yelkenlisi modeline dayalı bir grup müdahale programının üniversite öğrencilerinin kariyer seçimi ve kariyer kararları üzerine etkisi incelenmiştir. Bu makalede, grup sürecinin tamamına katılan üyeler arasından seçilen dördünün değerlendirilmesi yapılarak modelin uygulanışına ilişkin bilgi verilmesi amaçlanmıştır. Post-modern kuramların temel varsayımları dikkate alınarak uygulamada kullanılan bazı ölçekler, gruba ilişkin nicel bir veri değil, her bireye ilişkin nitel veri olarak üyelerin kendi değerlendirmelerini yapmaları amacıyla kullanılmıştır. $\mathrm{Bu}$ amaçla uygulamada grup sürecinin başında ve sonunda Mesleki Sonuç Beklentisi, Kariyer Kararı Yetkinlik Beklentisi ve Kariyer Geleceği Ölçekleri uygulanmıştır. Her oturumun sonunda üyelerden sözlü olarak duygu, düşünce ve kazanımları alınmış ve grup lideri tarafindan kaydedilmiştir. Her oturumda çeşitli farkındalıklar kazandıklarını ifade eden üyelerin grup süreci sonucunda ölçme araçlarından aldıkları puanların yükseldiği görülmüştür.

\section{A B S T R A C T}

In this study, the effect of a group intervention program based on the career sailing model on the career choice and career decisions of university students was examined. In this article, it is aimed to give information about the application of the model by evaluating the four selected members among the members of the group. Considering the basic assumptions of post-modern theories, some of the scales used in practice are not quantitative data about the group but used to make the members' own evaluations as qualitative data about each individual. For this purpose, Occupational Outcome Expectation, Career Decision Competency Expectation and Career Future Scales were applied at the beginning and end of the group period. At the end of each session, the members were verbally received emotions, thoughts and achievements and recorded by the group leader. It was observed that the scores of the members who expressed various awareness in each session increased as the result of the group process

\section{Giriş}

Hızla gelişen, değişen ve küreselleşen dünyada insanların günlük yaşamlarına ve insan ilişkilerine dair ihtiyaç ve beklentileri de değişmektedir. $\mathrm{Bu}$ bağlamda bireyin zamanının çoğunu, icra ettiği işe ve mesleğe ilişkin ortamlarda geçirdiği düşünüldüğünde, kariyer ve kariyerle ilişkili pek çok durum, yaşamda önemli bir yer tutmaktadır. Kariyer kavramı, bir ömür boyu yaşanan olaylar dizisi, bireyin meslek ve diğer yaşam rollerinin birbirini etkilemesi ve izlemesi sonucu oluşan genel örüntü ve gelişim çizgisinde, özellikle iş ve mesleğe ilişkin rollerinde ilerleme, duraklama ve gerilemeleri de içeren bir süreçtir (Herr ve Cramer, 1996).

Bireylerin kariyerlerinin nasıl oluştuğunu ve nasıl geliştiğini inceleyerek bu süreci olumlu etkilemeye çalışan kariyer danışmanlığı kuramlarının hepsi, içinde bulunduğu dönemin ve kültürün belirli ihtiyaçlarından yola çıkarak oluşturulmuştur. 20.yüzyılın başlarında ortaya kişi çevre

\footnotetext{
* Bu çalışma, 19-21 Ekim 2017 tarihlerinde Ankara'da düzenlenen 8. Uluslararası Eğitim Yönetimi Formu'nde bildiri olarak sunulmuştur.

** Sorumlu yazar/Corresponding author.

e-posta: betulgokcen.dogan@gmail.com
} 
uyumu modelleri, çalışanların işlerle nasıl eşleştirileceğine odaklanmışlardır. 20.yy.'ın ortalarında mesleki gelişim kuramları yaygınlık kazanmaya başlamış; kariyer gelişiminin sürdürülmesi ve mesleki gelişim görevlerinin yerine getirilmesi üzerine odaklanmıștır (Korkut-Owen ve Niles, 2011).

Ancak 21.yy'da küreselleşen ekonomi ile birlikte; iş dünyası ve işgücü piyasasında değişimler ortaya çıkmış, bazı meslekler yeniden yapılandırılmıştır. Kariyerin ne olduğuna ilişkin algı farklılaşmış ve kariyer daha değişken ve esnek bir örüntü olarak kabul edilmeye başlanmıştır (Yeşilyaprak, 2016). Bireylerin kişilik özelliklerinin gerçeği yansıttığı düşünülen ölçme araçları ile ölçülmesi yerine; insanların sahip oldukları özellikleri nasıl kullandıklarını anlama üzerine odaklanılmıştır. İnsanların benliklerini ve sosyal kimliklerini kaybetmeden iş ve meslek dünyası ile ilgili değişimlerin üstesinden nasıl gelebilecekleri konusu kariyer danışmanlığının cevap aradığı temel soru haline gelmiştir. Çünkü artık insanlar iyi bir ücret elde etmenin yanı sıra; sahip oldukları işte anlam bulmaya, aile ve meslek rolleri arasında denge sağlamaya, değişen iş görevlerinin gerektirdiği becerilere uyum sağlamaya, iş çevrelerini kontrol etmeye, duygusal zekâlarını kullanarak kariyer gelişim sürecinde karşılaştıkları stresli durumlarla etkili şekilde başa çıkabilmeye de gereksinim duymaya başlamışlardır (Savickas, 2012). Bu nedenle 21.yy şartlarında bireylerin yaşamlarını düzenlemelerine daha iyi destek sunabilmek için; kariyer danışmanlarının, bireylerin kişilik özelliklerinden çok mesleki kimlik gelişimlerine, kariyer olgunluğundan çok kariyer uyumuna, kesin yargılardan çok bireysel amaçlara ve ölçme araçları ile elde edilen puanlardan çok danışanların hikâyelerine odaklanmalarını gerektirmiştir. Post-modern kariyer kuramları bu bağlamda ortaya çıkan bütünleştirici yaklaşımlar olarak nitelendirilmektedir (Savickas, 2005).

Bu çalışmada uygulanan Kariyer Yelkenlisi Modeli de postmodern yaklaşımlara dayalı olarak Korkut-Owen vd. (2010) tarafından geliştirilmiştir.

\section{Kariyer Yelkenlisi Modeli}

Kariyer Yelkenlisi Modeli, bireyin kariyerinin bir yelkenli ile denizde yol almaya benzetilerek kullanılan metafor ile açıklanmaya çalışılmıştır. Buna göre; bireyin kariyer hedefi gideceği limanı temsil etmektedir. Bu limana onu götürecek yelkenlinin gövdesi bireysel özellikleri, bir yelkeni sosyal özellikleri diğer yelkeni ise sistemle ilgili özellikleri temsil etmektedir. Yelkeni hareket noktasından uzaklaştırıp onu farklı yönlere götüren dalga, rüzgâr gibi etmenler ise şansı temsil etmektedir. Bu model, dört etmeni ve bu etmenlerin birbiriyle etkileşimini ele alarak kişinin kendi hikâyesini oluşturmasını, böylelikle belirlemiş olduğu limana gitmesini sağlamaktadır.

Korkut-Owen (2008) kariyer yelkenlisi adı verilen modelde bireyin meslek seçimi ve kariyer sürecinde bu dört faktörün etkisinin olduğunu, bu etmenlerin bazılarının diğerine göre daha az ya da çok etkilediğini vurgulamışlardır. Bu etmenler kısaca şöyle tanımlanabilir:

(i) Bireysel etmenler: Bireylerin meslek seçimi ve kariyer gelişiminde ilgi, yetenek, değer, beklenti gibi kişisel özelliklerinin etkili olduğu savunulmaktadır. Bir birey kendi özelliklerini bilip bu özelliklerini karşılayacak meslekleri seçerse hem başarılı hem de mutlu olacaktır. Bireyin ilgisine, yeteneklerine ve değerlerine uygun bir meslek alanında çalışması, kariyer yelkenlisi ile çok daha uyumlu ve geliştirici bir şekilde ilerlemesini sağlayabilecektir.

(ii) Sosyal etmenler: Bu faktörün hem psikolojik hem de sosyolojik boyutu olduğu düşünülmektedir. Aile, kültür, gelenek gibi etmenlerden oluşmaktadır. Bireyin meslek seçiminde etkili biyolojik faktörler, anne ve babasından aldığı genler iken sahip olduğu yeteneği sergileyeceği ortamı sunan kişiler anne ve baba diğer bir ifade ile aile ortamıdır (Pişkin, 2002). Kültür ise, bireyin içinde yaşadığı toplum, aldığı eğitim, inançları onun düşünce biçimini dolayısıyla tercihlerini etkilemektedir. Dansçı olmak isteyip fakat çevresi tarafından onaylanmayacağını düşünüp farklı bir mesleğe yönelmek kültürün etkisine verilecek bir örnektir.

(iii) Sistemle ilgili etmenler: Bireyin içinde bulunduğu toplumun siyasi durumu, eğitim sistemi, yasalar, ekonomik durumu ve sınavların yapısı ve uygulanışı, işe girme, eğitim görme gibi etmenler bireyin meslek seçimi ve kariyeri üzerinde etkilidir.

(iv) Şans: Bireyin kariyer seçimlerinde bazen beklenmedik ve kontrol edilmeyen durumlar etkili olabilmektedir. Örneğin yaşanılan doğal afet, bir trafik kazası veya yüklü bir miras gibi...

Bu etkenleri dikkate alarak bireyin kariyerinde bu yönlerden kendini tanımasını ve değerlendirerek kariyerine bilinçli bir şekilde yön vermesini amaçlayan Kariyer Yelkenlisi Modeli, Türk kültürünü yansıtan bir özellikte oluşturulmuştur. Yeni bir model olarak uygulama ve araştırmalar ile sınanması, modelin geçerliğini test etmek açısından önemlidir. Ülkemizde farklı yaklaşım ve modeller ile yapılan grupla kariyer danışmanlığı müdahale programlarına ilişkin araştırmalar mevcuttur. Örneğin Çapri ve Gökçakan (2008) Akılcı Duygusal Davranışçı Terapi, Işık (2010), BüyükgözeKavas (2011) ve Sarı (2014) Sosyal Bilişsel Modele dayalı grupla kariyer danışmanlığı yürütmüşlerdir. Türkiye'de yapılan kariyer danışmanlığını post modern yaklaşımlardan Kaos kuramını ele alan Türkmen (2014) bireysel müdahale temelli bir araştırma yürütürken Gelibolu (2016) Kariyer Yelkenlisi, Erdoğmuş-Zorver (2013) Saviskas'ın Kariyer Yapılandırma Kuramı ile grup müdahelesi yürütmüşlerdir. Yurtdışında post modern yaklaşımlarla yapılan birçok grupla kariyer danışmanlığı müdahale programlarına rastlanmıştır. $\mathrm{Bu}$ araştırmalar; Brown'un Değer Temelli Yaklaşımı Berrios-Allison (2011), Duffy (2000) ve McKay vd. (2005), Brott'un Hikayelendirme yaklaşımı Bujold (2002) ve Clark vd. (2004), Saviskas'ın Yaşam Düzenleme Psikolojik Danışmanlığı Barclay ve Stoltz (2016)'dir. Ayrıca, araştırmalara göre grupla kariyer psikolojik danışma bireysel kariyer psikolojik danışmadan çok daha etkili olduğu yönünde bulgular mevcuttur (Damer vd., 2010; Siskind vd., 2008). Grubun mikrokozmoz özelliğinden dolayı grupla kariyer psikolojik danışması, bireylerin sosyal destek, sosyal beceri, öz yeterlilik ve içsel motivasyonun arttırdığ gözlenmiştir (Clark vd., 2004; Dennis vd., 2005; Fitch vd., 2012). Buradan hareketle Kariyer Yelkenlisi Modeli grup üzerinde yürütülmüş ve bu uygulama ile Kariyer Yelkenlisi Modelinin bireylerin kariyer seçimi ve kariyer kararları üzerinde etkililiği sınanmıştır. 


\section{Yöntem}

\subsection{Araștırmanın Modeli}

$\mathrm{Bu}$ araştırma üniversite öğrencilerinin kariyer seçim ve karar verme süreçlerinde Kariyer Yelkenlisi Modelinin etkisini ortaya koymayı amaçlayan betimsel araştırma türlerinden deneysel araştırmadır. Deneysel araştırma, araştırmacı tarafindan karşılaştırılabilir işlemler uygulandıktan sonra onların etkilerinin incelenmesidir (Büyüköztürk, KılıçÇakmak, Akgün, Karadeniz ve Demirel, 2010).

\section{2. Çalıșma Grubu}

Araştırmanın çalışma grubu, 2015-2016 eğitim-öğretim yılında çeşitli bölümlerde öğrenim görmekte olan 6'sı kadın, 4'ü erkek toplam 10 öğrenciden oluşmaktadır. Araştırmada incelenen öğrenciler planlanan süreci başından sonuna dek değerlendirmeye olanak verecek şekilde kariyer psikolojik danışma grubunun her oturumuna katıldığı için seçilmiş ve bu araştırma verileri onlar üzerinden elde edilmiştir. Aşağıda katılımcılar hakkında tanıtıcı bilgi tablo şeklinde sunulmuştur.

Tablo 1. Kat1lımc1lara Ait Temel Bilgiler

\begin{tabular}{|c|c|c|}
\hline Katılımcının adı & Katılımcı hakkında bilgi & Gruptaki Amac1 \\
\hline Ayşe & $\begin{array}{l}21 \text { yaşında, kadın, Sosyal } \\
\text { Bilgiler ögretmenliği } \\
\text { öğrencisi. }\end{array}$ & $\begin{array}{l}\text { Meslek alanımda } \\
\text { aktif ve kendini } \\
\text { geliştiren biri olmak. }\end{array}$ \\
\hline Burak & $\begin{array}{l}21 \text { yaşında, erkek, } \\
\text { Rehberlik ve psikolojik } \\
\text { danışmanlık öğrencisi. }\end{array}$ & $\begin{array}{l}\text { İsteyerek } \\
\text { gelmediğim } \\
\text { bölümüm hakkında } \\
\text { bilgi sahibi olup ona } \\
\text { göre yolumu çizmek. }\end{array}$ \\
\hline Cem & $\begin{array}{l}22 \text { yaşında, erkek, } \\
\text { Rehberlik ve psikolojik } \\
\text { danışmanlık öğrencisi. }\end{array}$ & $\begin{array}{l}\text { Mesleki } \\
\text { kararsızlığımı } \\
\text { netleştirmek. }\end{array}$ \\
\hline Derya & $\begin{array}{l}20 \text { yaşında, kadın, } \\
\text { Siyaset Bilimi ve Kamu } \\
\text { Yönetimi öğrencisi. }\end{array}$ & $\begin{array}{l}\text { Meslek alanım çok } \\
\text { geniş, hangi iş bana } \\
\text { uygun bunu } \\
\text { anlamak. }\end{array}$ \\
\hline
\end{tabular}

\subsection{Veri Toplama Araçları}

Katılımcılardan grupla kariyer psikolojik danışma süreci başlamadan önce ve beş oturumluk danışma süreci sonucunda Kişisel Bilgi Formu, Mesleki Sonuç Beklentisi Ölçeği (MSBÖ), Kariyer Kararı Yetkinlik Beklentisi Ölçeği (KKYBÖ) ve Kariyer Geleceği Ölçeği (Kargel) bireysel değerlendirme amaciyla uygulanmış ve puanlar kaydedilmiştir. Ayrıca, her oturum sonunda her üyeden tek tek "bugünkü duygu, düşünce ve kazanımları" alınmış ve grup lideri tarafindan kaydedilmiştir.

\subsubsection{Kişisel Bilgi Formu}

Araştırmada katılımcıların rumuz, cinsiyet, yaş, öğrenim görülen bölüm, sınıf düzeyi gibi kişisel bilgileri elde etmek amacıyla araştırmacı tarafindan hazırlanmıştır.

\subsubsection{Mesleki Sonuç Beklentisi Ölçeği (MSBÖ)}

McWhirter vd. (2000) tarafindan geliştirilen 12 maddelik ölçme aracı bireylerin mesleki sonuç beklentilerini belirlemektedir. Ölçme aracından alınan puanlar 12-48 arasında değişmekte olup puanlardaki artıs mesleğin ne kadar beklentilerini karşıladığını göstermektedir. Ölçme aracının Türkçeye uyarlama çalışmaları Işı (2010) tarafından gerçekleştirilmiş̧ir. Ölçme aracı orijinal yapısını koruyarak tek boyutta toplanmış, Cronbach Alfa iç tutarlık katsayısı 0.87 olarak bulunmuştur.

\subsubsection{Kariyer Kararı Yetkinlik Beklentisi Ölçeği (KKYBÖ)}

Betz vd. (1996) tarafindan geliştirilen KKYBÖ-KF, üniversite öğrencilerinin kariyerleriyle ilgili kararlar verme sürecinde gerekli olan görevler konusunda kendilerini yetkin görme düzeylerini belirlemek amaciyla kullanılmaktadır. Toplam 25 maddeden oluşan ölçme aracında puanların yüksekliği kariyer kararı verme yetkinliğine işaret etmektedir. Ölçme aracının Türkçeye uyarlama çalışmaları Işık (2010) tarafından gerçekleştirilmiştir. Ölçme aracı orijinal yapısını koruyarak tek boyutta toplanmış, Cronbach Alfa iç tutarlık katsayısı 0.81 olarak bulunmuştur.

\subsubsection{Kariyer Geleceği Ölçeği (Kargel)}

Rottinghaus vd. (2005) tarafindan geliştirilen Kariyer Geleceği Ölçeği bireylerin olumlu kariyer planlama tutumlarını değerlendirmek amacıyla geliştirilmiştir. Ölçme aracı Kariyer Uyumu, Kariyer İyimserliği ve İş Piyasasına İlişkin Algılanan Bilgi olmak üzere üç alt boyuttan ve toplam 25 maddeden oluşmaktadır. Ölçme aracının Türkçeye uyarlama çalışması Kalafat (2016) tarafindan yapılmıştır. Ölçeğin iç tutarlılık analizleri sonucu elde edilen değerler Kariyer Uyumu için 0.83 , Kariyer İyimserliği için 0.82 , İş Piyasasına İlişkin Algılanan Bilgi alt boyutu için 0.62 ve toplamda 0.88 bulunarak ölçeğin yeterli güvenirlik düzeylerine sahip olduğu görülmüştür. Yapılan madde ayırt ediciliği ve doğrulayıcı faktör analizi sonuçları, ölçeğin orijinal üç faktörlü yapısının Türk örneklemi için uygun olduğunu göstermiştir.

\subsection{Verilerin Toplanmas1}

2015-2016 bahar yarıyllnda bir devlet üniversitesinin öğrencilerine yönelik kariyer danışmanlığı yapılacağı duyurulmuştur. Duyurulara dayanarak araştırmaciya ulaşan öğrencilere kariyer grubu ve süreç hakkında kısa bilgi verilmiştir. Katılmak isteyen 10 gönüllü öğrenciden kariyer psikolojik danışma grubu oluşturulmuştur. Kariyer psikolojik danışma grubuna başlamadan önce üyeler MSBÖ, KKYBÖ ve KARGEL ölçme araçlarını doldurmuş, bu değerlendirme ön test olarak ele alınmıştır. Kullanılan ölçme araçları üyelere ilişkin nicel bir veri değil, her bireye ilişkin nitel veri olup, üyelerin kendi değerlendirmelerini yapmaları amacıyla kullanılmıştır. Kariyer Yelkenlisi Modeline dayalı kariyer grubu 5 oturumdan oluşmakta olup ilk oturum tanışma, amaçları belirleme, kariyer ve kariyer yelkenlisi hakkında bilgiyi içermektedir. İkinci oturumda kariyer yelkenlisinin gövdesini oluşturan bireysel etmenler ele alınmıştır. Bunun için "Bilgi, Nesne ve İnsan: Hangisiyle İlgilenmeyi Severim?" ve "Mesleki değer karalaması (Korkut-Owen vd., 2015)" etkinlikleri yapılmış ve değerlendirilmiştir. Üçüncü oturumda "aile pencerem" ve "kültürel öyküm (Korkut-Owen vd., 2015)" adlı etkinliklerle grup üyelerinin sosyal etmenleri incelenmeye çalışılmıştır. Dördüncü oturumda sistemle ilgili etmenler "Alaattin'in Kariyer Perisi (Korkut-Owen vd., 2015)" adlı etkinlik ile ele 
alınıp tartışılmıştır. Son oturum olan beşinci oturumda şans faktörü "Mesleki Dart (Korkut-Owen vd., 2015)" etkinliği ile konuşulmuştur. Sonrasında ele alınan etmenleri özetlemek ve üyelerin kendilerini en çok nelerin etkilediğini görmeleri için "etkinlik sonuçlarının gözden geçirilmesi" formu dağıtılmıştır. Böylelikle üyeler her etmeni değerlendirmişlerdir. Her oturum sonunda tüm üyelerden "duygu, düşünce ve kazanımları" alınarak kendilerini değerlendirmeleri istenmiştir. Son olarak ilk oturumda belirlenen amaçların ne kadarına ulaşıldığı sorularak grup sonlandırılmıştır. Son oturumda üyeler MSBÖ, KKYBÖ ve KARGEL ölçme araçlarını doldurmuş, bu değerlendirme son test olarak ele alınmıştır.

\subsection{Verilerin Analizi}

Ön test, son test puanları grup üyelerine ilişkin nicel bir veri değil nitel veri olup, üyelerin kendilerini değerlendirmeleri amacıyla kullanılmıştır. Tüm üyelerin her oturum sonundaki duygu, düşünce ve kazanımları tek tek incelenmiş bulgular bölümünde ele alınıp yorumlanmıştır. Nitel analiz yapılmıştır.

\section{Bulgular}

Tablo 2. Ayşe'nin Grupla Kariyer Psikolojik Danışma Öncesi ve Sonrası Değerlendirme Sonuçları

\begin{tabular}{|c|c|c|c|c|}
\hline & MSBÖ & KKYBÖ & KA & REL \\
\hline \multirow{2}{*}{ Ayşe } & Ön Test Son Te & Ön Test Son Tes & Dn Test & Son Test \\
\hline & 47 & 111 & 82 & 115 \\
\hline
\end{tabular}

Tablo 2'ye bakıldığında Ayşe'nin kariyer yelkenlisi grupla psikolojik danışma sonrasında Mesleki Sonuç Beklentisi, Kariyer Karar Yetkinlik Beklentisi ve Kariyer Geleceği Ölçeklerinden aldığı puanların pozitif yönde arttığı görülmektedir. Daha öz bir ifade ile Ayşe'nin seçmiş olduğu mesleğin beklentilerini karşılayabilmek için planlar yaptığ ve bu planlar sonucunda elde edeceği sonuçtan memnun olduğu söylenebilir.

1. oturumdaki duygu, düşünce ve kazanımları;

\begin{abstract}
"Ben arkadaşlarımı dinlerken çok üzüldüm eğitim sistemimiz ne halde, kimse istediği yerde değil dedim. Birey mesleğinde mutsuz olunca hayatta da mutsuz oluyor, yaşamını etkiliyor. Kendi kariyerim açısından da farkındalı̆̆ım arttı. Örneğin staja giden arkadaşlarım sistemin kötülüğünden bahsediyor bu da beni soğutuyor işimden ama şu an bir şeyler yapmalıyım bir eğitimci olarak sistemin, yeni neslin bu karamsarlığını çözmeliyim dedim."
\end{abstract}

Tanışma, amaçların belirlenmesi, kariyer ve kariyer yelkenlisi hakkında kısa bilgiyi içeren ilk oturum sonunda danışanın hem kendi hem de diğer üyeler için farkındalık kazandığı söylenebilir. Ayşe'nin bir şeyler yapma, etkin rol alma düşüncesi tetiklenmiştir. Kariyerin bireyin yaşamında ne kadar büyük öneme sahip olduğunu fark etmiştir.

2. oturumdaki duygu, düşünce ve kazanımları;

\footnotetext{
“Öğretmenliğin tam bana göre olduğunu gördüm, iyi ki bu bölümdeyim dedim. Öğrencilere bir şeyler ögretmek, arta kalan zamanımı kendime ve çocuklarıma ayırmak çok güzel."
}

Bireysel özelliklerin ele alındığı ikinci oturum sonunda Ayşe, eğitimini aldığ1 mesleğin onu yansıttığını, kişisel özellikleri ile paralellik gösterdiğini görüp mutlu olmuştur.

3. oturumdaki duygu, düşünce ve kazanımları;
"Meslek seçimimde çevremdeki kişilerin rollerini fark ettim. Olumlu ya da olumsuz açıları vardır bunu biliyordum ama bu kadar etkisi olduğunu hiç daha önce fark etmemişstim. Yaptığımız etkinlik ile kadına biçilen meslekler ve bunu fark etmeden kabul edişimiz çok etkileyiciydi benim için."

Seçimlerimizde sosyal etmenlerin rolünü ele aldığımız üçüncü oturum sonunda Ayşe, aslında kendi kişisel özellikleri ile örtüştüğünü düşündüğü mesleğini seçmesinde ailesinin ve kültürün etkisini fark etmiştir. Bir kadın olarak en uygun mesleğin öğretmenlik olduğunu aslında bir şekilde düşüncelerine bunun yerleştiğini ve bunu kendi düşüncesi gibi nasıl kabul edip benimsediğinin ayırdına varmıştır.

4. oturumdaki duygu, düşünce ve kazanımları;

"Diğer oturumlarda benim seçimlerimde beni etkileyen
faktörleri gördüm bugün de bu faktörleri çıkarıp kendim
olarak seçimim nasıl olurdu diye değerlendirdim. Kaygım
azaldı, daha rahat bir seçim yaptım. Baskı azaldı, kültürün
etkisi azaldı. İlgim olan şeyleri herkesten bağımsız tercih
edebildim."

İlk oturumda seçimlerinde kimsenin etkisinin olmadığını, tam da istediği mesleğin eğitimini aldığını dile getiren danışan dördüncü oturumda onu etkileyen faktörleri çıkararak bağımsız seçim yapmanın keyfine varmıştır. Böylelikle daha mutlu olduğunu görmüştür.

5. oturumdaki duygu, düşünce ve kazanımları;

\begin{abstract}
"Kariyerime bıkmadan devam etmek benim gruba başlarken amaç olarak belirlediğim şeydi. Bıkmamam için bireysel kaygl ve stresi ortadan kaldirmam gerekiyordu. Bunlar zincir halinde birbirine bağll şeylerdi. Grup ile beni sıkan şeyi gördüm bununla nasıl baş edeceğimi biliyorum, bunu hayata geçirirsem her şey güzel olacak. Atanıp ögretmen olduktan sonra Tarih okuyacağım."
\end{abstract}

Danışan son oturumda onda kaygı uyandıran etmenleri fark ettiğini ve bu etmenlerle mücadele edebileceğini dile getirmiştir. İlk oturumda kendisine en yakın bulduğu mesleği icra ettiğini söylerken her oturumda aslında bu tercihin tam anlamıyla kendisine ait olmadığını görmüştür. İçinde bulunduğu mesleği bir merdiven olarak kullanıp esas istediği mesleği okuyacağını dile getirmiş ve böylece gerçek kariyer hedefini belirlemiştir.

Tablo 3. Burak'ın Grupla Kariyer Psikolojik Danışma Öncesi ve Sonrası Değerlendirme Sonuçları

\begin{tabular}{|c|c|c|c|c|c|c|}
\hline & Ms & BÖ & KK & YBÖ & KAR & RGEL \\
\hline \multirow{2}{*}{ Burak } & Ön Test & Son Test & Ön Test & Son Test & Ön Test & Son Test \\
\hline & 29 & 36 & 73 & 93 & 84 & 84 \\
\hline
\end{tabular}

Tablo 3'e bakıldığında Burak'ın kariyer yelkenlisi grupla psikolojik danışma sonrasında Mesleki Sonuç Beklentisi, Kariyer Karar Yetkinlik Beklentisi ve Kariyer Geleceği Ölçeklerinden aldığı puanların pozitif yönde arttığı görülmektedir. Daha öz bir ifade ile Burak, seçmiş olduğu mesleğin daha çok beklentilerini karşılayan, Burak'ın kariyerinde daha kararlı bir hale geldiği ve daha iyi planlar yapabildiği söylenebilir. 
1. oturumdaki duygu, düşünce ve kazanımları;

"Sorunların, sikıntıların ortak olduğunu gördüm. Rahatladım, eskisi gibi umutsuz vakayım demedim kendime. Paylaşmanin önemini gördüm ve bu bana iyi geldi."

Burak, grupla psikolojik danışmanın mikrokozmoz özelliğini yaşayabilmiştir. Daha önce paylaşılmamış, dile getirilmemiş duygular bu ilk oturumda konuşulunca aslında yalnız olmadığını farklı bölümlerde okuyan, farklı sınıflardaki bireylerin de kendisine benzer kaygıları olduğunu görmüştür. Bu durum onu hem şaşırtmış hem de yalnız olmadığını anlamasını sağlamıştır.

2. oturumdaki duygu, düşünce ve kazanımları;

\begin{abstract}
“Kariyerime yönelik düşündüğüm ve karar veremediğim ama bir türlü adını koyamadı̆ıı şeyler vardı. Bugünkü etkinlikler ve paylaşımlarla bunlar netleşti. Bu beni rahatlatt, en büyük kazancım bu oldu."
\end{abstract}

Kişisel etmenlerin ele alındığ 1 ikinci oturum sonunda Burak'ın kendine yönelik farkındalığı artmıştır. Mesleki değer, ilgi ve yetenekleri ile kişisel ilgi, yetenek ve değerleri arasında bağ kurmak Burak’1 rahatlatmıştır.

3. oturumdaki duygu, düşünce ve kazanımları;

\begin{abstract}
"Anne baba ile ilgili konuştuk ama arkadaşın etkisini konuşmadık belki sonra konuşuruz. Ben daha çok onların kendim üzerindeki etkisini düşündüm. Onların negatif etkisi falan. Sinıfta mesela kızın biri ben yüksek lisans yapacağım dedi öyle bir dalga oldu ki herkes yüksek lisans yapmayı planliyor. Yüksek lisans yapmayacak olan ben en kötü danışman olacakmış gibi bir hava oluştu. Ailem daha çok etkiliyor seçimlerimi, tolere edebildiğimi düşünsem de arkadaşlarımın etkisi de varmış üzerimde."
\end{abstract}

Burak, seçimlerinde ailesinin etkisinin olduğunun farkında olan birey ama arkadaşlarının da onu etkilediğini üçüncü oturumda fark etmiştir. Burak, ailesinin seçimleri üzerindeki etkisini destekleyici ve kucaklayıcı bulurken, arkadaşlarının etkisinin onda "yetersizlik" duygusu yarattığını hissetmiştir. Ancak bu durum onda kariyer hedeflerini yükseltme yönünde teşvik edici olabilir.

4. oturumdaki duygu, düşünce ve kazanımları;

"Çok üşengeç olduğumu fark ettim. Sevdiğim şeyler için harekete geçmem gerektiğini gördüm. Her şey aslında benim elimde. Kendime daha çok güveniyorum. Irademin ellerimde olduğunu hissediyorum. Atın dizginleri var ya o dizginler ellerimde ona ben yön vereceğim."

Danışan kariyer geleceğini şekillendirenin yalnızca kendisi olduğunu fark etmiş bu farkındalık onun motivasyonunu arttırmıştır. Danışmanın bu farkındalık ile somut ve gerçekçi hedefler belirleyeceği düşünülebilir.

5. oturumdaki duygu, düşünce ve kazanımları; “Gelecek kaygısını azaltmak bu gruba gelme amacımdı. Ne
olacak nasıl olacak diye sürekli düşünüyordum. Şu an her
şeyin benim elimde olduğunu gördüm. Bölüm tercihim beni
çok sarstl, Türkiye'nin sistemsel yapısı ve ailemin etkisi
falan istediğim yerde olmamı engelledi. Ama kendime
güvenim artt, her şey benim elimde, bu hayat benim, bu
düşüncelerle kaygım azaldı. Pişmanlı̆ğm arttı sistemsel
olarak istediğim bölümü tercih edemedim. Ben sosyolog
olmak istiyordum ama iş kaygısı beni PDR okumaya
yönlendirdi. Bundan sonra sosyolog olarak çalışmayı
neden istediğimi belirleyip bunu PDR'ye uyarlayacağım.
Örneğin okulda çalışmayacağım, bakanlıklarda çalışacă̆ım, yüksek lisans yapacağım, çalıșma alanım Sosyoloji olacak."

Danışan grupla psikolojik danışmanın son oturumunda istediği mesleği icra edemeyecek olmanın hayal kırıklığını yaşarken, neden tercih edemediğini belirlemek onu rahatlatmıştır. Danışanı sosyolog olmaya iten özellikleri belirleyerek şu an eğitimini aldığı bölüme uygulayacağını belirtmesi dördüncü oturumda belirttiği gibi dizginleri eline aldığının göstergesidir. Burak, sürece başlamadan önce kendisine belirlediği amaca ulaşmış bir biçimde; hedeflerini gerçekleştirme yolunda sorumluluk alması gerektiğini kabul ederek ve motivasyonunu artarak süreci tamamlamıştır.

Tablo 4. Cem'in Grupla Kariyer Psikolojik Danışma Öncesi ve Sonrası Değerlendirme Sonuçları

\begin{tabular}{ccccccc}
\hline & \multicolumn{2}{c}{ MSBÖ } & \multicolumn{2}{c}{ KKYBÖ } & \multicolumn{2}{c}{ KARGEL } \\
\hline \multirow{2}{*}{ Cem Ön Test } & Son Test & Ön Test & Son Test & Ön Test & Son Test \\
\cline { 2 - 7 } & 37 & 44 & 88 & 109 & 84 & 86 \\
\hline
\end{tabular}

Tablo 4'e bakıldığında Cem'in kariyer yelkenlisine dayalı grupla psikolojik danışma sonrasında Mesleki Sonuç Beklentisi, Kariyer Karar Yetkinlik Beklentisi ve Kariyer Geleceği Ölçeklerinden aldığı puanların pozitif yönde arttığı görülmektedir. Daha öz bir ifade ile Cem'in seçmiş olduğu meslek artık daha çok beklentilerini karşılamaktadır. Cem'in kariyerinde daha kararlı hale geldiği ve daha iyi planlar yapabildiği söylenebilir.

1. oturumdaki duygu, düşünce ve kazanımları;

"Sonuca ilişkin beklentim arttı. Konuşmaktan çok memnum oldum. Farkl bölümlerden gelmiş bireyler olsak da ortak kaygllarımı beni memnun etti, mutlu oldum."

Cem, grupla psikolojik danışmanın mikrokozmoz özelliğini ilk oturumda hissetmeye başlamıştır. Bu durum onun diğer oturumlara güdülenmiş bir şekilde gelmesini sağlayacaktır.

2. oturumdaki duygu, düşünce ve kazanımları;
"Nasıl bir iş yaparım ögretmen mi olurum akademisyen mi olurum onun kararinı hala veremedim ama nasl bir ortamda çalışmayacağımı biliyorum artık. Ankara gibi karışı, gürültülü, koşturmalı bir yer değil de daha sakin küçük şehirleri tercih edeceğim. Bir şeyler netleşmeye başladl, mutlu oldum."

Bireysel etmenlerin ele alındığı ikinci oturumda Cem, kendinden çok çalışma ortamı ile ilgili farkındalıklar kazanmıştır. Bu farkındalık onun çalışacağı iş ile ilgili karar verme sürecinde kolaylık sağlayacaktır.

3. oturumdaki duygu, düşünce ve kazanımları;
"Ailem dışında seçimlerimde kimsenin etkisinin olmadı̆̆ını bir kez daha teyit ettim, gördüm. Bir miktar bu etkinin farkındaydım da yine de bunun yüzde yüz değil de yüzde elli etkisinin olduğunu gördüm."

Sosyal etmenlerin ele alındığı üçüncü oturum sonunda Cem, seçimlerinde sadece ailesinin etkisinin olduğunu görmüştür.

4. oturumdaki duygu, düşünce ve kazanımları;

\footnotetext{
"Ütopiklikten gerçek yaşama pat diye geçtim biraz ama doyum yaşadım. Arada sirada aklıma gelen hayalleri bir kez daha değerlendirdim. Arkadaşlarımla yaptığım paylaşımlar yalnız değilim dedirtti ve hoşuma gitti. Grup ile bağım gelişti."
} 
Cem, sistemsel etmenlerin istek ve arzularına ulaşmayı engellediğini dördüncü oturumda görmüştür. Kişinin iradesi dişında gelişen olaylar bazen onun seçimlerini etkileyebilmektedir. $\mathrm{Bu}$ durum, sistemsel etmenlerin seçimleri nasıl etkilediğini görerek, Cem'e yalnız olmadığını hissettirmiştir.

5. oturumdaki duygu, düşünce ve kazanımları;

\begin{abstract}
"Sürece başladı̆̆ımızda kendime amaç olarak mesleki kararlarımda özgüvenimi yükseltmeyi belirlemiştim. Şu an gerçekten yükselttiğimi düşünüyorum, kendime inanıyorum. Yapacağım şeyler için vereceğim ara beni korkutmuyor aksine cesaretlendiriyor. Arada sirada duraklama dönemi yaşasam da istediğim yere geleceğim. İşimi bulduktan sonra tekrar LYS'ye girip Antropoloji ya da Dil Bilimi okumayı hedefliyorum."
\end{abstract}

Cem, ilk oturumda kendine belirlediği amacına ulaşmıştır. Danışanın mesleki özgüveninin artması onun motivasyonunu arttırmıştır. Cem, kariyer hedeflerini belirlemiş; iş sahibi olup para kazandıktan sonra ilgisini çeken Antropoloji ya da Dil Bilimi bölümlerini okumaya karar vermiştir.

Tablo 5. Derya'nın Grupla Kariyer Psikolojik Danışma Öncesi ve Sonrası Değerlendirme Sonuçları

\begin{tabular}{|c|c|c|c|c|c|}
\hline & MSBÖ & $\overline{K K}$ & YBÖ & $\mathrm{K}$ & GEL \\
\hline \multirow[b]{2}{*}{ Derya } & Ön Test Son Test & Ön Test & Son Test & Ön Test & Son $\mathrm{Te}$ \\
\hline & 31 & 66 & 68 & 81 & 85 \\
\hline
\end{tabular}

Tablo 5'e bakıldığında Derya'nın kariyer yelkenlisi grupla psikolojik danışma sonrasında Mesleki Sonuç Beklentisi, Kariyer Karar Yetkinlik Beklentisi ve Kariyer Geleceği Ölçeklerinden aldığı puanların pozitif yönde $\operatorname{arttığı~}$ görülmektedir. Daha öz bir ifade ile Derya'nın seçmiş olduğu mesleğin daha çok beklentilerini karşılayarak kariyerinde daha kararlı bir hale geldiği ve daha iyi planlar yapabildiği söylenebilir.

1. oturumdaki duygu, düşünce ve kazanımları;

\begin{abstract}
"Kendimi rahatlamış hissediyorum, benim gibi düşünenlerin olduğunu görmek mutlu etti beni. Buradan çıkınca daha önce düşündüğüm şeyleri yine düşüneceğim ama daha bilinçli bir düsünce olacak bu. Mesela 5 oturum yapacağız, 2. oturumun sonunda her şey mükemmel olmayacak ama bir şekilde beni etkileyecek, bana güzel şeyler kazandiracak."
\end{abstract}

Derya için grupla kariyer danışmasının ilk oturumu Burak ve Cem gibi mikrokozmoz özelliği göstermiştir. Derya farkındalık kazanarak kariyer geleceğini daha olumlu ve somut bir biçimde anlamaya başlamıştır.

2. oturumdaki duygu, düşünce ve kazanımları;

\begin{abstract}
"Çalışabileceğim ortam ne kalabalık ne sakin olmall, kalabalık bir ortam olsa da sonunda odama çekilip çalışmalıyım. Penceremden baktı̆̆ımda araba gürültü̈sü duymamalı ve şehrin karmaşasını görmemeliyim. Aslında ben fakültemin arka bahçesini, oradaki ağaçları görmek istiyorum. Aktif değil de proaktif olarak, yönlendiren olarak alanıma bir şeyler katmak istiyorum. Sanırım ben akademisyen olmak istiyorum. Bu daha önce hiç düşünmediğim bir şeydi, bu düşünce hoşuma gitti ve beni rahatlattı."
\end{abstract}

Derya, yapılan etkinlikler sonunda daha önce düşünmediği bir mesleği düşünmeye başlamıştır. Kariyer hedefinin netleşmeye başlaması Derya'nın kaygılarının azalmasını sağlamıştır.

3. oturumdaki duygu, düşünce ve kazanımları;

\begin{abstract}
"Kariyer ya da başka seçimlerimde ailemin ya da başkalarının etkisini fark etmiştim ama bu kadar büyük bir etkisi olduğunu şu an anladım. Annemin etkisi olduğunu babamın da desteği olduğunu düşünürdüm hep şu an aslında babamın da tercihlerimde nasıl büyük bir etkisinin olduğunu gördüm."
\end{abstract}

Derya, seçimlerinde kendisi dışında önem verdiği herkesin etkisi olduğunu görmüştür. Derya'nın kendisini ve seçimlerini daha iyi tanımaya başladığı söylenebilir.

4. oturumdaki duygu, düşünce ve kazanımları;

\begin{abstract}
"Gelmek zorunda kaldiğım bölümü aslında kendim seçtiğimi düşünüyormuşum, benim meğerse tercihlerimde ailemin, sistemin ne kadar çok etkisi varmış. Ben sadece gidiyorum, yapıyorum ve geliyormuşum. Bunu fark ettiğim için artık seçeceğim meslekte kendi isteklerimi belirleyip buna göre tercih yapacağım.'
\end{abstract}

Derya'nın seçimlerindeki farkındalığı daha çok artmış, bu da onun kendi isteklerini ön plana çıkarmasını sağlamıştır. Kendisini ve isteklerini bilen Derya'nın kariyer seçiminde sorumluluk almaya hazır hale geldiği düşünülebilir.

5. oturumdaki duygu, düşünce ve kazanımları;

\begin{abstract}
“Amacım kendimi tanıyı mutlu olacağım mesleği seçebilmekti. Gerçekten de klsa sürede kendimi daha iyi tanıyı neyi istediğimi gördüm. Aslında kendim tercih ettim dediğim bölümü ben değil ailem tercih etmiş. İdari hâkim olacağım derken de annemin dediğini yapıyormuşum. Ben aslında çalışmalarımı masamda yapıp sunmayı, bir kitleye ulaşmayı istiyorum. Adalet dağıtıp sürekli şehir değiştirmek istemiyorum. Ben ne olmak istediğimi fark ettim, akademisyen olmak istiyorum. Bu bana en uygun meslek."
\end{abstract}

Derya, ilk oturumda kendisine belirlemiş olduğu amaca ulaşmıştır. Derya'nın hemen hemen tüm oturumlarda elde ettiği farkındalık onun kısa sürede amacına ulaşmasını ve kariyer hedeflerini netleştirmesini sağlamıştır.

\section{Sonuç}

Alan yazın incelendiğinde, Kariyer Yelkenlisi Modeli, bireyin özellikleriyle meslekleri eşleştiren kuramlara alternatif olabileceği, dahası eksikliklerini tamamlayabileceğiyle ilgili iyimser işaretler sunmaktadır (Korkut-Owen ve Niles, 2011). Kariyer Yelkenlisi Modeli Sistem Kuramı, Ekolojik Bakış Açısı, Planlanmış Şans Kuramı, Mesleki Teleskop Modeli ve Yapılandırmacı bakış açılarından esinlenilip Türkiye'yi yansıtan bazı özelliklere sahip bir modeldir.

Kariyer Yelkenlisi Modelinde ele alınan her bir etmen mesleki gelişime ve kariyer sürecine doğrudan uygulanabilir niteliktedir. Günümüz koşullarında kariyer oluşumu pek çok faktöre bağlıdır. Eğitim sisteminin Türkiye'nin politik yapısına bağlı olup sürekli değişim göstermesi, dönem dönem bazı mesleklerin yıldızı parlarken bazılarında istihdam koşullarının azalması, ailelerin çocuklar üzerindeki baskı ve dayatmaları bunlardan bazılarıdır. Modelin, meslek seçiminde sadece bireysel değil çok daha farklı etmenlerin rolünü de ele alması bireyin, meslek edinme ve değiştirme sürecine adaptasyonunu kolaylaştırdığı düşünülmektedir. 
Geleneksel yaklaşımlar sadece mesleğin özellikleri ile bireyin özelliklerini eşleştirmeye dayalı olması bakımından eleştirilmektedir. Savickas (2002), danışmanlık sürecinde ölçme araçlarının kullanımının ya da diğer bir ifadeyle nicel yöntemlerin yanında, nitel yöntemlerin de kullanılmasının gerekli olduğunu belirtmektedir. Kariyer sürecinde bireyin yetenek, ilgi, kişilik ve başarı düzeyi çeşitli ölçme araçları tarafından nesnel bir şekilde ölçülmektedir. Ancak kariyer sürecinde birey için uygun kararın alınmasında ölçme araçları önemli fakat yeterli bilgi sağlamamaktadır. Bu nedenle post-modern yaklaşımlar bireyin kişisel olarak kendi kariyer gelişim sürecini anlaması ve bu süreci etkileyen etmenlerin farkına vararak yönetmesi konusunda sorumluluk almasına odaklanır.

Kariyer Yelkenlisi Modeli hem çağdaş bir yaklaşım olup değişen dünya şartlarına ayak uyduran, bireyin ihtiyaçlarını ön plana alan hem de Türk kültürünü yansitan bir yaklaşımdır. Modeli ortaya koyan Korkut-Owen vd. (2010) tarafından kariyer psikolojik danışmanlığında kullanılacak, bireyin kariyer hedeflerine yönelik farkındalığını artıracak etkinlikler sunulmuştur. Bu etkinlikler sayesinde modelin uygulanması kolaylaşmıştır. Grup üyeleri ile varılan nokta düşünüldüğünde, her üye bütün kariyer yaşantısını Kariyer Yelkenlisi Modelinin kavramları çerçevesinde değerlendirmiş ve yine aynı çerçevede bir karara ulaşarak uygulamaya koymaya hazır hale gelmiştir. Üyeler her oturum sonunda sözlü olarak neler kazandıklarını belirtmişlerdir. Ayrıca kariyer psikolojik danışmanlığı öncesinde ve sonrasında grubun genel amacına uygun ölçme araçları uygulanmış, her üyenin sözel olarak verdiği geri bildirimleri destekler sonuçlar elde edilmiştir. Bu bakımdan Kariyer Yelkenlisi Modeline dayalı olarak yürütülen kariyer grupla psikolojik danışmanlığının faydalı olduğu düşünülmektedir. $\mathrm{Bu}$ çalışmadan elde edilen bulgular Gelibolu'nun (2016) grupla müdahale çalışmasıyla paralellik göstermektedir

$\mathrm{Bu}$ çalışmadan yola çıkarak gelecek çalışmalarda Kariyer Yelkenlisi Modelinin grupla kariyer psikolojik danışma sürecine uygulanması yararlı görülmüştür. Elde edilen sonuçların, modelin Türk kültürüne, grup sürecine ve kariyer gelişimine uygunluğunun test edilmesi bakımından alan yazına katkı sağladığı düşünülmektedir. Daha önce Kariyer Yelkenlisi Modelini ele alan, etkililiğini araștıran araştırmaya rastlanmamıştır, bu araştırma ilk olması yönünden önem taşımaktadır. $\mathrm{Bu}$ uygulamadan yola çıkılarak, bu tür araştırmaların çoğalması ve geniş alana yayılmasıyla Kariyer Yelkenlisi Modelinin etkililiğiyle ilgili soru işaretlerine cevap bulunmuș olacağı düşünülmektedir. Diğer yandan Kariyer Yelkenlisi Modeli uygulamalarının eğitim kurumlarında yaygınlaştırılması ve bunların test edilmesi de alandaki uygulamacılara yarar sağlayabilir.

\section{Kaynakça}

Barclay, S. R., \& Stoltz, K. B. (2016). The life-design group: A case study assessment. The Career Development Quarterly, 64(1), 83-96.

Berríos-Allison, A. C. (2011). Career support group for Latino/a college students. Journal of College Counseling, 14(1), 80-95.
Betz, N. E., Klein, K. L., \& Taylor, K. M. (1996). Evaluation of a short-form of career decision making self-efficacy scale. Journal of Career Assessment, 4, 47- 57.

Bujold, C. (2002). Constructing career through narrative. Journal of vocational behavior, 64(3), 470484.

Büyükgöze-Kavas, A. (2011). Testing a model of career indecision among university students based on Social Cognitve Career Theory. Doktora Tezi. Ankara: Orta Doğu Teknik Üniversitesi.

Büyüköztürk, Ş., Çakmak, E. K., Akgün, Ö. E., Karadeniz, Ş., \& Demirel, F. (2010). Bilimsel araştırma yöntemleri. Ankara: Pegem Akademi Yayınları.

Clark, M. A., Severy, L., \& Sawyer, S. A. (2004). Creating connections: Using a narrative approach in career group counseling with college students from diverse cultural backgrounds. Journal of College Counseling, 7(1), 2431.

Çapri, A. G. B., \& Gökçakan, Z. (2008). Akılcı duygusal davranış terapisi ADDT'ne dayalı grupla psikolojik danışmanın üniversite öğrencilerinin problem çözme becerisi algısına etkisi. Çukurova Üniversitesi Sosyal Bilimler Enstitüsü Dergisi, 17(1), 135-154.

Damer, D. E., Latimer, K. M., \& Porter, S. H. (2010). "Build your social confidence": A social anxiety group for college students. The Journal for Specialists in Group Work, 35(1), 7-22.

Dennis, J. M., Phinney, J. S., \& Chuateco, L. I. (2005). The role of motivation, parental support, and peer support in the academic success of ethnic minority first-generation college students. Journal of college student development, 46(3), 223-236.

Duffy, J. A. (2000). The application of chaos theory to the career-plateaued worker. Journal of Employment Counseling, 37(4), 229-236.

Erdoğmuş-Zorver, C. (2013). Savickas'in kariyer yapılandırma kuramına dayalı örnek bir kariyer grup danışmanlığı çalışması. 1. Uluslararası İş ve Meslek Danışmanlığ Kongresi. Ankara İŞ-KUR.

Fitch, T., Marshall, J., \& McCarthy, W. (2012). The effect of solution-focused groups on self-regulated learning. Journal of College Student Development, 53(4), 586-595.

Gelibolu, S. (2016). Kariyer yelkenlisi modeli temelli hazırlanan mesleki grup rehberliği programının sınanması. 7. Uluslararası Eğitim Araştırmaları Kongresi. Onsekiz Mart Üniversitesi, Çanakkale.

Herr, E.L., \& Crammer, S.H. (1996). Career guidance and counseling through the lifespan. New York: HarperCollins Publishers.

Işık, E. (2010). Sosyal bilişsel kariyer teorisi temelli bir grup müdahalesinin üniversite ögrencilerinin kariyer kararı yetkinlik ve mesleki sonuç beklenti düzeylerine etkisi. Doktora Tezi. Adana: Çukurova Üniversitesi.

Kalafat, T. (2016). Kariyer Geleceği Ölçeği (KARGEL): Türk örneklemi için psikometrik özelliklerinin 
incelenmesi. Türk Psikolojik Danışma ve Rehberlik Dergisi, 4(38), 169-179.

Korkut-Owen, F. (2008). Meslek seçimini etkileyen etmenler. (Ed. R. Özyürek) Mesleki yolculuk (ss. 1-16), Ankara: Ulusal Ajans.

Korkut-Owen, F., \& Niles, S. C. (2011). Kariyer danışmanlığında yeni kuramlar ve yaklaşımlar. (Edit. B. Yeşilyaprak), Kariyer danışmanlığı: Kuramdan uygulamaya, (ss.273-307), Ankara: PegemAkademi.

Korkut-Owen, F., Açıkel, M., Arıcı, F., Çağ, P., Demirtaş, S., Emir, E., Erdoğmuş-Zorver, C., İpekçi, B., Küçükay, A., Mutlu, T., Saka, E., \& Ülker, G. (2010). Mesleki rehberlik/kariyer danışmanlığ 1 için bir model önerisi: Kariyer yelkenlisi modeli, 12.Rehberlik sempozyumu, AREL Okulları, İstanbul, 27 Mart 2010.

Korkut-Owen, F., Mutlu Süral, T., Arıcı Şahin, F., \& Demirtaş Zorbaz, S. (2015). Kariyer Yelkenlisi Modeli: Kendilerine uygun limanı arayanlar için çalışma el kitabı. Ankara: Anı Yayıncılık.

McKay, H., Bright, J. E., \& Pryor, R. G. (2005). Finding order and direction from chaos: A comparison of chaos career counseling and trait matching counseling. Journal of Employment Counseling, 42(3), 98-112.

McWhirter, E. H., Rasheed, S., \& Crothers, M. (2000). The effects of high school career education on socialcognitive variables. Journal of Counseling Psychology, 47, 330-341.

Pişkin, M. (2002). Çocuğun kariyer planlamasında ailenin rolü. İçinde: 2001 Yll Aile Raporu. (s.245-272). Ankara: T.C. Başbakanlık Aile Araştırma Kurumu Yayınları.

Rottinghaus, P. J., Day, S. X., \& Borgen, F. H. (2005). The Career Futures Inventory: A measure of careerrelated adaptability and optimism. Journal of Career Assessment, 13(1), 3-24.

Sarı, S.V. (2014). Sosyal bilişsel öğrenme teorisine dayalı grup müdahalesinin üniversite ögrencilerinin kariyeraraştırma öz yeterliklerine etkisi. Doktora Tezi. Trabzon: Karadeniz Teknik Üniversitesi.

Savickas, M. L. (2002). Career Construction: A developmental theory of vocational behavior. İçinde D. Brown and Associates (eds.). Career Choice and Development (Fourth Edition). San Francisco: JosseyBass.

Savickas, M. L. (2005). The theory and practice of career construction. career development and counseling: putting theory and research to work. In: S. D. Brown \& R. W. Lent (Eds.) (s. 42-70). New York: Wiley.

Savickas, M. L. (2012). Life design: A paradigm for career intervention in the 21 st century. Journal of Counseling and Development, 90(1), 13-19.

Siskind, D., Baingana, F., \& Kim, J. (2008). Costeffectiveness of group psychotherapy for depression in Uganda. The journal of mental health policy and economics, 11(3), 127-133.

Türkmen, M. (2014). Kaos kuramına dayalı kariyer psikolojik danışmanlığı programı ve vaka analizi. Türk
Psikolojik Danışma ve Rehberlik Dergisi, 5(42), 256268.

Yeşilyaprak, B. (ed) (2016). Mesleki rehberlik ve kariyer danışmanlı̆̆ kuramdan uygulamaya. Ankara: Pegem Akademi. 